\title{
Sensory Evaluation of Dry Persimmons of the Tipo (Diospyros kaki L. f.) Variety
}

\author{
Andrej Vogrin*, Petra Marko, Tatjana Unuk \\ University of Maribor, Faculty of Agriculture and Life Sciences, Pivola 10, 2311 Hoče, Slovenia
}

\begin{abstract}
The study carried out at the Faculty of Agriculture and Life Sciences of the University of Maribor aimed to evaluate the attractiveness of dried persimmon fruit depending on the method of preparing the fruit for drying. The methods varied in terms of the ripeness of the fruit, the thickness and shape of the slices, the presence of seeds (in fertilised fruits) and the presence of peel. Sensory evaluation was performed by students and staff, using a hedonic scale, where evaluators evaluated the appearance (shape and colour) and taste (sugar-acid ratio, texture, tartness, presence of fruit peel, and general impression) of the fruit. Dried unfertilized persimmons, with the presence of peel, cut into $3 \mathrm{~mm}$ thick slices, were given the highest score for overall attractiveness. In terms of taste, unfertilised, peeled persimmon slices scored the highest. Considering all parameters, the results showed that unfertilised persimmons were more suitable for drying and that the presence of the peel was not a disturbing factor for consumers.
\end{abstract}

Key words: Persimmon, fruit drying, hedonic sensory evaluation

\section{INTRODUCTION}

Persimmon is a fruit that grows in subtropical and moderately warm climate zones. In recent years, interest in persimmon production has increased strongly, which can be attributed to favourable market conditions and undemanding production technology. Owing to climate change and new varieties, it is now possible to produce persimmon in regions of Slovenia where that was not the case two decades ago, e.g. in Styria (Štajerska) (Rupčić, 2017), Prekmurje and Posavje. Consumers are interested in the consumption of persimmon because of its good taste, high nutrient levels and healing properties (Ambrožič Turk et al., 2009). Consequently, the production area increased from 28.1 to 55.9 hectares between 2009 and 2015. According to the Statistical Office of Slovenia, persimmon production area reached 107.2 hectares in 2017 (SURS, 2017). Both dried persimmons and fresh persimmons, represent a food of high nutritional value.
The objective of the study performed at the Faculty of Agriculture and Life Sciences of the University of Maribor was to determine how the method of preparation of fresh fruit and their maturity level affect the sensory evaluation of dried persimmon and potential acceptance by consumers.

\section{Drying of persimmons}

The fruit is best if eaten fresh; if dried, persimmon can be served as an alternative to various kinds of sweets. Drying is the oldest, most natural and rational way of preserving food (Miklošič, 1998). Each preservation method should prevent the enzymatic and microbiological changes that cause food spoilage (Kerin, 1988). During drying, physical and chemical changes occur; the shape changes as the fruit wrinkles and shrinks, and the concentration of minerals and organic matter increases (most noticeably, the sugars and acids), 
owing to a reduction in the amount of water. Volatile aromatic substances can be lost by water evaporation. Smaller losses occur when drying at lower temperatures. The content and concentration of aromas change compared to those of fresh fruit and become less pronounced. The change of fruit skin and meat colour during drying is smaller in case of higher acid content (Pirc, 1990). The duration of drying varies and depends on the thickness of the chunks or slices (Pirc, 1990, Škof, 2003), air humidity, temperature and ventilation intensity.

The process of drying persimmons differs, depending on how fresh fruit are prepared and which method of drying is used. Persimmons can be dried partially ripe or fully ripe, either softened or not, we can choose between fertilised or unfertilised fruits. Fruit can be prepared for drying in different ways (drying whole fruit, chunks or slices of various thickness). Whether the fruit is fertilised, its ripeness, the preparation of the fruit and the method of drying will determine the appearance, colour and the taste of the dried persimmons.

There are several possible approaches to drying persimmon fruit (Cortese: 2003, Nicoleti et al., 2004). It is possible to dry ripe or partially ripe fruit, whole or fruit cut into thin or thick slices, fresh or pre-treated with low temperatures or antioxidants. According to the method of preparation the final product - dried persimmons - differs greatly in colour and taste (Cortese, 2003).

It was confirmed that during the drying process sugar increases, the colour of the flesh changes and becomes more intensely orange-red, while the amount of acids is reduced (Jurhar Grabnar, 2016). The sugars present in the fruit are often excreted on the surface, where they crystallise. The tannin content that causes astringency depends on the maturity of the fruit as well as on whether the fruit were fertilised (presence of seeds). Nicoleti et al. (2004) report that drying temperature affects the breakdown of tannins. Chung et al. (2017) observed how the removal of astringency by freezing before drying affects the sensory evaluation of dry persimmon slices and found that freezing lowers the soluble tannin content. Karakasova et al. (2015) also used fresh persimmons and fruit that were frozen for 24 hours before drying. Drying pre-frozen fruit resulted in a more pleasant taste. The same authors pointed out the possibility of fruit colour manipulation (the retention of light colour) by dipping the fruit slices into $\mathrm{K}_{2} \mathrm{~S}_{2} \mathrm{O}_{5}$ solution before drying. On the other hand, Jurhar Grabnar (2016) reported that the use of softened (ripe) fruit results in a more intense orange-red colour compared to fruit that were still firm before drying. So, it is general accepted that if the fruits are not fertilised and do not contain seeds (or have a low number of seeds), the astringency level requires softening (ripening) before the fruit are edible. The flesh colour of these fruit is yellow-orange (Sancin, 1988). According to Vrhovnik (2006), the fruit of fertilised and unfertilised persimmons can be distinguished externally. Fruit with seeds are rounder in shape at the top, with a cracked skin in the form of concentric black circles. The astringency breakdown can also be achieved by exposing the fruit to temperatures between 20 and $25^{\circ} \mathrm{C}$ for $5-7$ days until they become soft. Another method is in chambers with added $\mathrm{CO}_{2}$ for 24 to 72 hours (Sancin, 1988), whereby the fruit lose tartness and remain firm.
According to Jurhar Grabnar (2016), unripe, firm and therefore astringent persimmon fruit can be successfully used for drying. These contain a higher amount of tannins compared to softened fruit, which will be reduced during drying (in both softened and non-softened persimmon fruit.

\section{Sensory evaluation}

According to Golob et al. (2005a), sensory evaluation methods are divided into analytical or hedonic. The former are performed by trained evaluators or experts, while the latter are used by random, untrained evaluators. Hedonic sensory analysis is most often used during the development process of new products to control the quality of raw materials, to find the causes of unwanted changes in certain sensory properties (colour, smell, taste, aroma or texture) and to determine the potential acceptance of the product by consumers (Golob et al., 2005b). The same author lists various hedonic rating scales allowing product likeability evaluation, using simple rating scales (facial, visual or descriptive). To this effect, bipolar rating scales with two points marked with opposite values at each end (left side: very unpleasant, right side: very pleasant) are used. Evaluators mark the likeability of a given rating parameter on a straight line; the closer the mark to the start of the line, the lower the likeability rating and vice-versa. In turn, the score on the line is converted into a number serving as the basis for statistical data processing.

\section{MATERIALS AND METHODS}

Fruit of the "Tipo" persimmon variety were grown on the Marko farm in the settlement of Metava, near Maribor, Slovenia. This organic farm with two persimmon orchards is located at an altitude of 325 meters. The first orchard measures 0.07 hectares and comprises trees of the "Tipo" and "Čokolatino" varieties. Most fruit of the "Tipo" variety are fertilised and contain seeds. The second plantation, measuring 0.06 hectares, includes only the "Tipo" variety, and the fruit of these trees are not fertilised. The rootstock is a seedling (Diospyros kaki). At the time of the experiment, the trees were 7 years old. The two plantations are 350 meters apart.

The fruit of the "Tipo" variety are suitable for harvesting in the second half of October or the beginning of November. The fruit containing many seeds are fertilized and are edible hard, immediately after harvest. These fruit have darker orange flesh.

The persimmon fruit were harvested on November 22, 2018. The drying of the fruit took place between 23 November and 16 December 2018. Until drying, the fruit were stored in a refrigerator at $4^{\circ} \mathrm{C}$. The preparation of the fruit for drying varied, depending on the method of drying used. In general, fertilised and unfertilised, softened and not softened, as well as peeled or not peeled persimmon fruit were used. The fruit were cut into slices of different thickness or into chunks. The experiment consisted of 7 treatments:

UPS3 - unfertilised fruit, peeled and cut into $3 \mathrm{~mm}$ thick slices, (dried for 17 hours and 4 minutes); 
- $\quad$ UPS7 - unfertilised fruit, peeled and cut into $7 \mathrm{~mm}$ thick slices, (dried for 20 hours);

UPS10 - unfertilised fruit, peeled and cut into $10 \mathrm{~mm}$ thick slices; (dried for 42 hours and 50 minutes);

UUS7 - unfertilised fruit, cut, unpeeled into $7 \mathrm{~mm}$ thick slices, (dried for 40 hours and 45 minutes);

UPC - unfertilised fruit, peeled and cut into chunks (chunks were $5 \mathrm{~mm}$ thick at the narrower part and 10 mm thick at the widest), (dried for 39 hours and 37 minutes);

- $\quad$ FPS7 - fertilised fruit, peeled and cut into $7 \mathrm{~mm}$ thick slices, (dried for 24 hours and 30 minutes);

FSPS7 - fertilised and softened fruit, peeled and cut into $7 \mathrm{~mm}$ thick slices (the fruit were left at room temperature $\left(22^{\circ} \mathrm{C}\right)$ for five days to soften; they were subsequently sliced and dried), (dried for 22 hours and 30 minutes);

The fruit were dried in the Suša 6 dryer (SUŠA 6, Okorn, Slovenija) (chamber size: $0,309 \mathrm{~m}^{3}$ ) at a constant temperature of $40^{\circ} \mathrm{C}$. For each treatment, 70 samples (slices or chunks) were prepared and weighed before drying. The drying time varied, depending on the thickness of the slices (drying time ranged from 17 hours and 4 minutes for slices $3 \mathrm{~mm}$ thick, to 42 hours and 50 minutes for slices $10 \mathrm{~mm}$ thick). During drying, the weight of the samples was monitored. Drying was completed when the dried persimmons accounted for $20 \%$ of the initial weight. The dried persimmons were appropriately labelled and stored in hermetically sealed plastic containers in a cool place.

\section{Sensory evaluation of dried persimmons}

Hedonic sensory evaluation (Golob at al., 2005a) of the dried persimmons took place on January 10, 2019 at the Faculty of Agriculture and Life Sciences of the University of Maribor. Students and employees of the faculty participated in the evaluation. The evaluation was attended by 65 inexperienced evaluators, aged 19 to 65 . Their task was to evaluate the likeability (acceptability) of different quality parameters of the dried fruit: their appearance (shape and colour); the parameters defining taste (sugar-acid ratio, texture and astringency); and the overall impression of each individual sample. For the UUS7 sample, the evaluators also evaluated the likeability of the peel presence.

In the first part, the appearance of each sample was evaluated. Plastic plates were marked with three-digit codes. On each plate were ten randomly selected slices/chunks. Mutual comparison of samples was not possible. The order of evaluation was written on the sheets. The order of evaluation differed from one evaluator to the other and did not affect the result.

In the second part, taste parameters and the general impression of the samples were evaluated. Each evaluator received seven plates, each marked with a three-digit code. On each plate there was one slice/chunk of dried persimmon. The samples were covered, which made it impossible to compare the samples with each other. Each evaluator had a glass of fresh water available to neutralise the taste during the evaluation of samples.

\section{Statistical analysis}

Statistical analysis was performed using Statgraphics Centurion XV (Statgraphic, 2005) software. To determine statistically significant influences, Multifactor ANOVA was used. The results presented in the table are mean values with standard error $( \pm$ SEM). Differences between mean values were determined with multiple comparison test (Duncan, a $=0,05)$.

\section{RESULTS AND DISCUSSION}

The results of the analysis of variance are shown in Table 1. The subjective evaluator grade represents an important source of variation $(\mathrm{p} \leq 0.001)$; the reasons are the differences in perception of each property by the individual evaluator. An important source of variability in the assessment of

Table 1: Evaluation of the likeability of individual parameters of dried persimmons

\begin{tabular}{|l|c|c|c|c|c|c|c|}
\hline $\begin{array}{l}\text { Source of variation / } \\
\text { Sensory property }\end{array}$ & Shape & Colour & Sugar/acid ratio & Texture & Astringency & General impression \\
\hline Evaluator & $3.19^{* * *}$ & $2.29^{* * *}$ & $3.26^{* * *}$ & $3.23^{* * *}$ & $5.42^{* * *}$ & $2.97^{* * *}$ \\
\hline Treatment & $51.43^{* * *}$ & $45.57^{* * *}$ & $11.86^{* * *}$ & $11.23^{* * *}$ & $3.85^{* * *}$ & $11.39^{* * *}$ \\
\hline Treatment: & \multicolumn{7}{|c|}{ Mean value \pm SEM } \\
\hline UPS3 & $8.1 \pm 0.19 \mathrm{a}$ & $7.8 \pm 0.23 \mathrm{a}$ & $6.3 \pm 0.28 \mathrm{~b}$ & $6.8 \pm 0.29 \mathrm{ab}$ & $6.3 \pm 0.31 \mathrm{bc}$ & $6.6 \pm 0.29 \mathrm{a}$ \\
\hline UPS7 & $7.6 \pm 0.23 \mathrm{ab}$ & $7.7 \pm 0.24 \mathrm{a}$ & $6.9 \pm 0.24 \mathrm{ab}$ & $7.3 \pm 0.23 \mathrm{a}$ & $6.7 \pm 0.29 \mathrm{ab}$ & $6.9 \pm 0.27 \mathrm{a}$ \\
\hline UPS10 & $6.5 \pm 0.25 \mathrm{c}$ & $6.0 \pm 0.26 \mathrm{~b}$ & $7.3 \pm 0.22 \mathrm{a}$ & $6.8 \pm 0.32 \mathrm{ab}$ & $7.1 \pm 0.31 \mathrm{a}$ & $6.8 \pm 0.27 \mathrm{a}$ \\
\hline UUS7 & $7.1 \pm 0.22 \mathrm{~b}$ & $7.4 \pm 0.21 \mathrm{a}$ & $7.1 \pm 0.24 \mathrm{a}$ & $6.1 \pm 0.30 \mathrm{bc}$ & $6.7 \pm 0.31 \mathrm{ab}$ & $6.5 \pm 0.28 \mathrm{a}$ \\
\hline UPC & $4.1 \pm 0.32 \mathrm{~d}$ & $5.1 \pm 0.30 \mathrm{c}$ & $7.3 \pm 0.28 \mathrm{a}$ & $7.0 \pm 0.30 \mathrm{a}$ & $7.2 \pm 0.31 \mathrm{a}$ & $7.0 \pm 0.28 \mathrm{a}$ \\
\hline FPS7 & $4.3 \pm 0.26 \mathrm{~d}$ & $3.9 \pm 0.30 \mathrm{~d}$ & $5.6 \pm 0.33 \mathrm{c}$ & $5.7 \pm 0.31 \mathrm{c}$ & $6.4 \pm 0.30 \mathrm{abc}$ & $5.5 \pm 0.31 \mathrm{~b}$ \\
\hline FSPS7 & $4.8 \pm 0.33 \mathrm{~d}$ & $4.1 \pm 0.34 \mathrm{~d}$ & $5.3 \pm 0.30 \mathrm{c}$ & $4.8 \pm 0.33 \mathrm{~d}$ & $5.8 \pm 0.33 \mathrm{c}$ & $4.7 \pm 0.32 \mathrm{c}$ \\
\hline
\end{tabular}

*** Statistically significant at $\mathrm{p} \leq 0.001$. Mean values $( \pm$ SEM), marked with different letters, show statistically significant differences $($ Duncan test, $\alpha=0.05)$. 
attractiveness of individual parameters is the treatment itself $(\mathrm{p} \leq 0.001)$.

\section{Shape}

The highest statistically significant score for shape was given to the samples that were treated under UPS 3 and UPS7 (8.1 and 7.6 of 10). In both treatments, unfertilised, peeled fruit were used. Statistically, the lowest scores were awarded to samples from fertilised fruit that were cut in chunks (UPC, FPS7, FSPS7 - 4.1, 4.3, 4.8 of 10). Regarding the UUS7 (7.1 of 10) treatment, the interesting shape of the unpeeled samples was pointed out, the evaluators adding that the peel completed the shape of the dried persimmon. The shape of the chunks (UPC - 4.1 of 10) was described as less attractive. The lowest average grades for attractiveness of shape in the FPS7 and FSPS7 treatments can be attributed to the use of fertilised fruit. These contain up to eight seeds, which were removed while slicing the fruit. During drying, the slices twisted because of the holes in the flesh, which negatively affected the final appearance.

\section{Colour}

According to the evaluators, the most attractive colour occurred in the UPS3 (7.8 of 10) and UPS7-treated samples (7.7 of 10). In both treatments, unfertilised fruit were used. The samples had a bright yellow-orange colour. In the FPS7 (3.9 of 10) and FSPS7 (4.1 of 10) treatments, fertilised fruit were used. It appears that this was the reason for the lowest average scores for colour, which was dark orange and brownish. The FSPS7 samples were prepared from softened fruit and became markedly darker in colour. According to Zhou et al. (2011), the level of carotenoids in persimmon fruit increases as they ripen, and they become darker in colour. The same phenomenon was observed in the dried samples prepared from fertilized persimmon fruit and was in line with the observations of Jurhar Grabnar (2016), who pointed out the intense orange-red shade of mature fertilized persimmon fruit. Some evaluators noted that the UPS3 samples with the highest average grade had an attractive, noble colour. Tannin spots (brown colour), also observed in some samples, had a negative effect on appearance.

\section{Sugar/acid ratio}

The UPS10 and UPC samples received the highest average score (7.3 of 10$)$ for the sugar/acid ratio parameter. The UPS10 samples were cut into slices $10 \mathrm{~mm}$ thick, while the UPC comprised samples where fruit were cut into chunks. In both treatments, the fruit were dried for a longer time (drying time: UPS10 - 42 hours and 50 minutes, UPC - 39 hours and 37 minutes). UPS7 (6.9 of 10) and UUS7 (7.1 of $10)$, which were prepared from unfertilised fruit, received statistically significant similar scores for the attractiveness of the taste. Samples from treatments FPS7 (5.6 of 10) and FSPS7 (5.3 of 10) received the lowest average score; both were prepared from fertilised fruit.
Some evaluators added that they had detected higher sugar content in the fertilised fruit, most likely because of lower astringency. Mature (ripe) persimmon fruit are known to contain higher sugar levels compared to persimmon fruit that were not mature before drying (Kim and Jung, 2011). At the same time, the reduction of acid levels during the drying process, which was highlighted by Jurhar Grabnar (2016), has a direct impact on the sugar/acid ratio, and thus determining the taste.

On the surface of FPS7 and FSPS7 dried fruit slices, sugar crystals could be observed. This phenomenon is frequent in dried fruit and has been observed by Nicoleti et al. (2004), according to whom the process of water evaporation from the fruit is accompanied by the extraction and crystallization of sugar on the surface of the fruit. It was remarked by some evaluators that the $10 \mathrm{~mm}$ thick slices in the UPS10 treatment of unfertilised fruit were too sweet. A $10 \mathrm{~mm}$ thick slice of persimmon was dried under the same conditions $\left(40^{\circ} \mathrm{C}\right)$ for much longer than the $3 \mathrm{~mm}$ slice; during this time, however, the dry matter content increased, and consequently, more sugars were present, which could have disturbed the sugar/ acid ratio.

\section{Texture}

Evaluators preferred the texture of dried persimmons cut into thicker slices or chunks. In general, the texture of unfertilised persimmons received a higher score (FSPS7 4.8 and FPS7 - 5.7; other treatments ranged from 6.1 and 7.3 of 10). An unpleasant rubbery structure in the samples prepared from fertilised fruit was observed by some evaluators. If the fruit were treated by cutting into chunks, the texture was described as the most firm and pleasant. Evaluators commented that for the UPS3 treatment $(3 \mathrm{~mm}$ slices), complete dehydration of the slices would have been more appropriate and would have resulted in crispness. The results obtained this way possibly would have been similar to those of Milczarek et al. (2017), who decided to dry $5 \mathrm{~mm}$ persimmon slices to the texture of chips, trying to establish whether texture had a greater impact on the overall score of dried persimmon than aroma.

\section{Astringency}

The highest average scores for astringency were recorded in samples where the fruit were cut into chunks (UPC treatment -7.2 of 10 ) and in the thickest slices (UPS10 treatment -7.1 of 10$)$. The UPS7 (6.7 of 10) and UUS7 (6.7 of 10) samples were of the same thickness but differed in the presence of the peel. In both treatments, the fruit slices were dried for same amount of time. The UPS3 (6.3 of 10) samples, which were dried for the shortest time (17 hours and 4 minutes), received the lowest average score among unfertilised samples. The FPS7 (6.4 of 10) and FSPS7 (5.8 of 10) samples, which lost their astringency before drying, were not evaluated more highly than the samples that were unripe and inedible before drying. Although the level of tannins is reduced by maturing, it is pointed out by Juhar Grabner 
(2016) that drying persimmon has the same effect, regardless of how mature the fruit are. The same observation has been corroborated by the present study.

\section{General impression}

The last parameter was the edibility and overall acceptability of the dried persimmons. The fruit cut into chunks and dried using the UPC (7.0 of 10) method received the highest average score. The samples of unfertilised persimmon were awarded the highest statistically significant score. The statistically significant lowest score was awarded to the two samples of fertilised fruit. The lowest score was given to the sample comprising fertilised and extra softened persimmon (FSPS7 treatment -4.7 of 10 ).
The results show that non-mature persimmon fruit are more suitable for drying than mature fruit.

\section{Peel presence}

The next category was comparison of two samples that were prepared from unfertilised (firm) persimmons. The fruit were cut into $7 \mathrm{~mm}$ thick slices; one sample included the peel. A comparison of these two samples showed that the presence of the peel had a statistically significant effect only on the texture of the sample, which can be seen from Figure 1. There were no statistically significant differences in other parameters. The unfertilised peeled slice received a higher average score for texture (7.3 of 10) than the unfertilised peeled slice (6.1 of 10$)$.

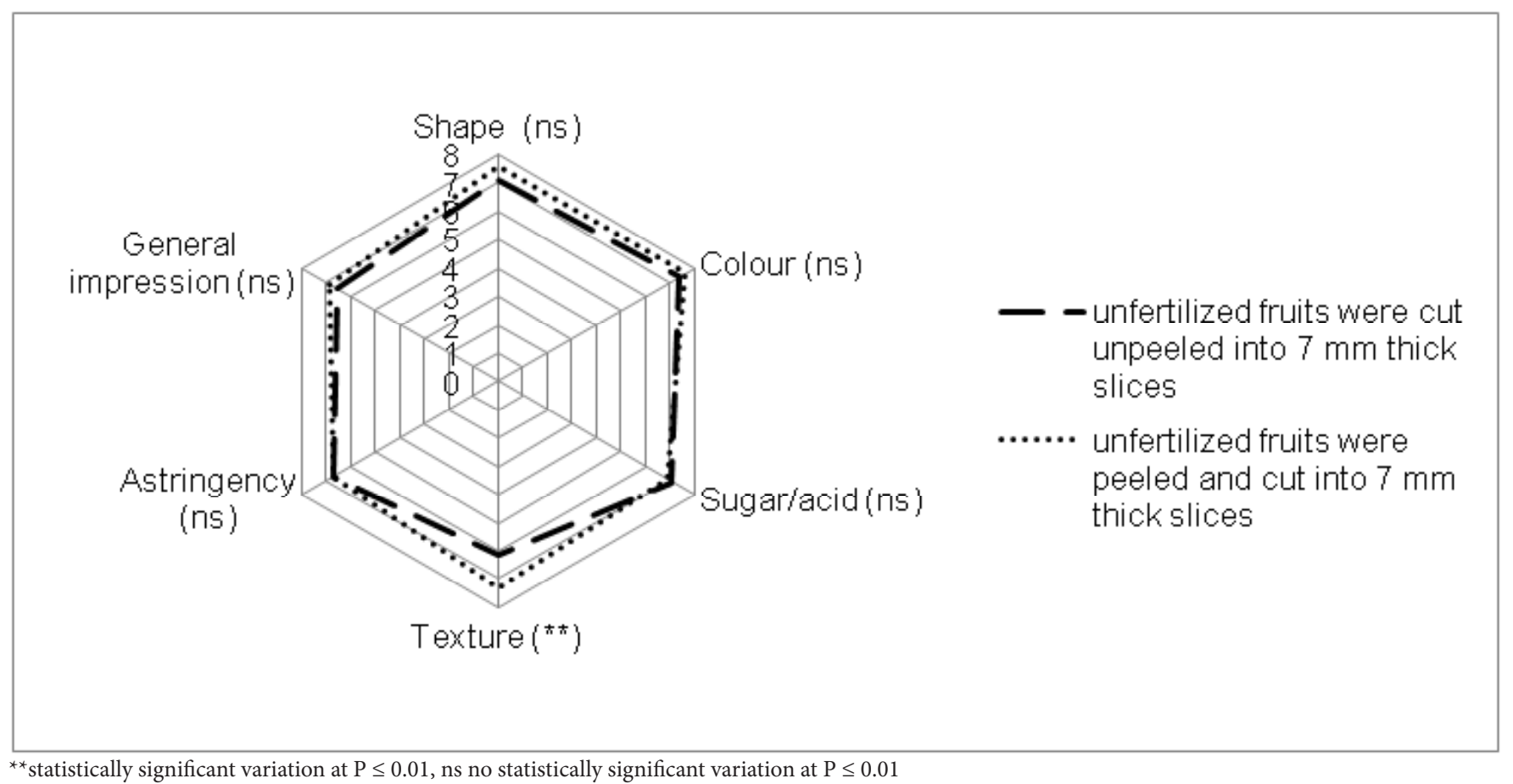

Figure 1: Evaluation of quality parameters of peeled and unpeeled dried persimmon.

The average score for the sample with the peel was 5.3 out of 10 . The evaluators noted that if the peel was thin enough, it completed the shape of the dried persimmon. The evaluators did not consider the presence of the peel a negative property, so removal of the fruit skin before drying was an unnecessary measure. Hand-peeling persimmons is a time-consuming task. The peel develops an even more intense orange shade during drying, emphasising the colour of the entire slice.

\section{Connection between the presence of seeds and the ripeness of fruit in the evaluation of dried fruit quality parameters}

The experiment also included a comparison of persimmon samples that were cut into slices $7 \mathrm{~mm}$ thick but differing in terms of the presence of seeds and the firmness of the fresh fruit (UPS7, FPS7, and FSPS7). Figure 2 shows that the preparation method used had a statistically significant effect on the attractiveness of the shape, colour, sugar-acid ratio, texture, and overall impression, but had no effect on astringency.

Unfertilised persimmon, peeled and cut into slices $7 \mathrm{~mm}$ thick (UPS7), received the highest average scores across all evaluated parameters. The shape of the dried persimmon received an average score of 7.6 out of 10 , which was statistically significantly different from the samples obtained by the other two treatments (FPS7 and FSPS7). The UPS7 treatment was given the highest score for texture (7.3 of 10), which was statistically significantly higher compared to the other two treatments. The lowest average score for texture (4.8 out of 10) was awarded to samples from the FSPS7 treatment.

The results of sensory evaluation of the "Tipo" dry persimmons suggest that sliced unfertilised fruit seems to be 


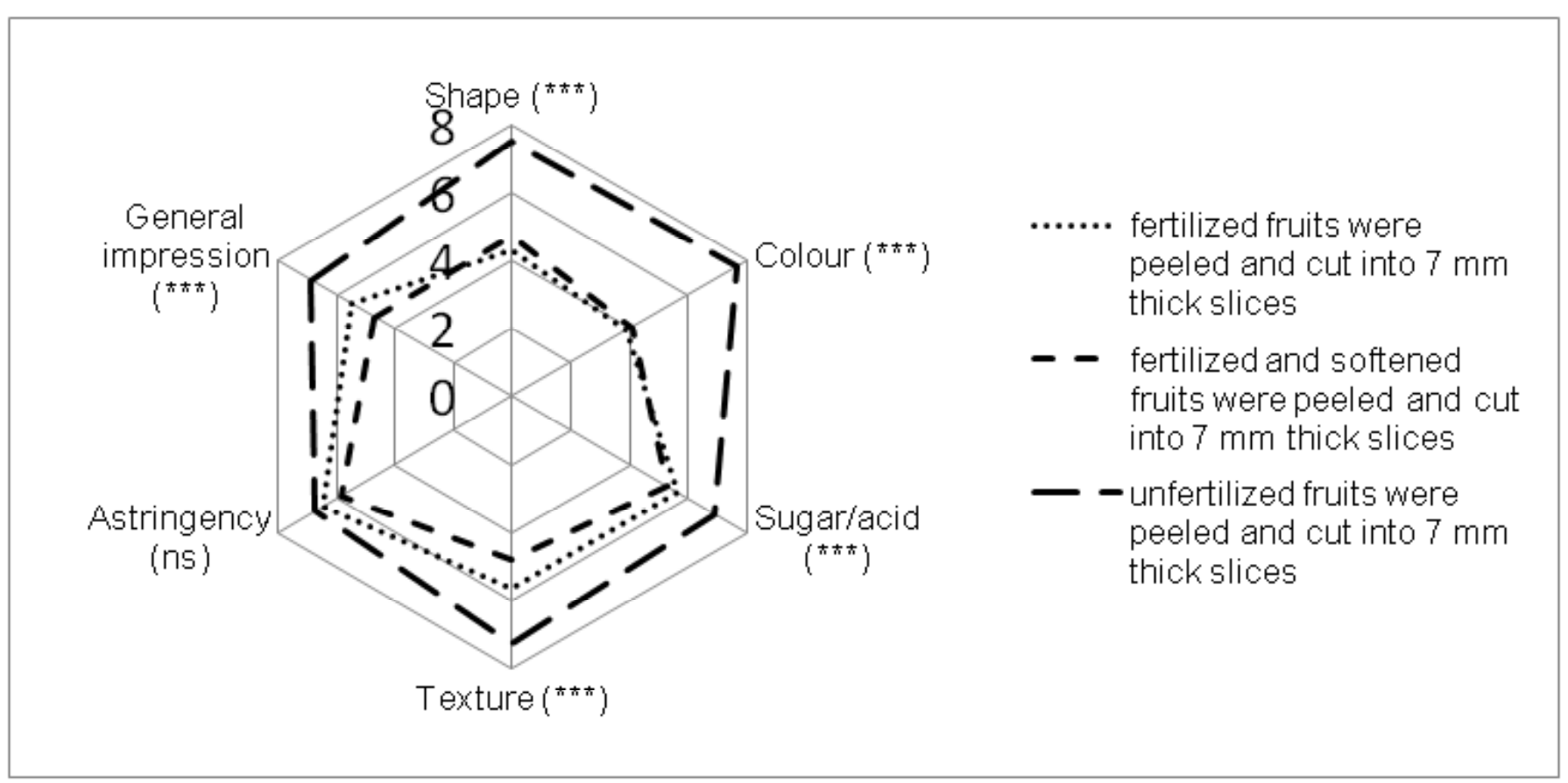

${ }^{* *}$ statistically significant variation at $\mathrm{P} \leq 0.01$, or $n$ s statistically significant variation at $\mathrm{P} \leq 0.01$

Figure 2: Comparison of average scores for $7 \mathrm{~mm}$ slices of dried persimmon with different preparation methods.

preferred by the evaluators; in terms of taste, unfertilised persimmons cut into chunks were the preferred option. In addition, the results showed that unfertilised persimmons were the most suitable type of fruit for drying. Given that dried persimmons in chunks were awarded the highest score for taste, this shape is more suitable for mixtures with other dried fruit, in our opinion, while sliced fruit (regardless of their thickness) are more suitable for selling on their own.

\section{CONCLUSION}

The method of preparation was the decisive factor that made the difference in the sensorial evaluation of dried persimmon fruit. Based on the results of the study, it can be concluded that evaluators and potential buyers prefer thinner slices of dried persimmon. In terms of colour, fruit with lighter colour are the most preferred option. Persimmons that are cut into thicker slices or chunks before drying are the preferred option, since they retain more flavour during the drying process. Unfertilised and non-softened fruit are more suitable for drying, while the presence of the peel does not have an adverse effect on the sensory properties of dried persimmons.

\section{REFERENCES}

1. Ambrožič Turk, B., Fajt, N., \& Komel, E. (2009). Rezultati preizkušanja sort kakija $\mathrm{v}$ razmerah jugozahodne Slovenije. SAD, 20, 1-3.

2. Chung, H. S., Kim, D. H., Kim, H. S., Lee, Y. G., Seong, J. H., Youn, K. S., \& Moon, K. D. (2017). Quality comparison of dried slices processed from whole persimmons treated with different deastringency methods. Food Science and Biotechnology, 26(2), 401-407.

3. Cortese, D. (2003). Suho sadje, zelenjava, zelišča in gobe. Sušenje in priprava jedi. Ljubjana, Kmečki glas, 16(37), 64-65.

4. Golob, T., Jamnik, M., Bertoncelj, J., \& Doberšek, U. (2005a). Senzorična analiza: metode in preskuševalci. Ljubljana: Biotehniška fakulteta.

5. Golob, T., Bertoncelj, J., Doberšek, U., \& Jamnik, M. (2005b) Senzorična analiza živil. Ljubljana: Biotehniška fakulteta.

6. Jurhar Grabnar, J. (2016). Sestava izbranih primarnih in sekundarnih metabolitov pri različnih sortah kakija (Diospyros kaki Thunb.) ter spremembe med zorenjem in sušenjem. MA thesis. Ljubljana: Biotehniška fakulteta.

7. Karakasova, L., Babanovska-Milenkovska, F., Lazov, M., Blagoj, K., \& Stojanova, M. (2015). Quality properties of solar dried persimmon (Diospyros kaki). Journal of Hygienic Engineering and Design, 4, 54-59.

8. Kerin, D. (1988). Sadje v naši prehrani. Ljubljana: Kmečki glas.

9. Kim, J. S., \& Jung, K. M. (2011). Effects of the PPO (polyphenol oxidase) activity and total phenolic contents on browning and quality of dried persimmon according to maturity degree of astringent persimmon (Diospyros kaki Thumb.). 2nd International Conference on Biotechnology and Food Science, 7, 115-118.

10. Miklošič, M. (1998). Sušenje sadja in zelenjave (njihove zdravilne lastnosti). Ljubljana: Samozaložba.

11. Milczarek, R. R., Woods, R. D., LaFond, S. I., Breksa, A. P., Preece, J. E., Smith, J. L., Sedej, I., Olsen, C. W., \& Vilches, A. M. (2017). Synthesis of descriptive sensory attributes and hedonic rankings of dried persimmon 
(Diospyros kaki sp.) Food Science \& Nutrition, 6(1), 124136.

12. Nicoleti, J. F., Vivaldo, S. J., Romero, T. J., \& Telis, N. R. V. (2004). Ascorbic acid degradation during convective drying of persimmons with fixed temperature inside the fruit. Proceedings of the 14th International Drying Symposium, 1836-1843.

13. Pirc, A. (1990). Sušenje sadja. Ljubljana: Kmečki glas.

14. Rupčić, A. (2017). Obseg pridelave izbranih sadnih vrst v Sloveniji. BA thesis. Ljubljana: Biotehniška fakulteta.

15. Sancin, V. (1988). Sadje z našega vrta. Trst: Založništvo tržaškega tiska.

16. SURS (Statistični urad Republike Slovenije). (2017). $\mathrm{Z}$ jablanami je zasajena več kot polovica intenzivnih sadovnjakov v Sloveniji. Retrieved from: https://www. stat.si/StatWeb/News/Index/7390

17. Škof, D. (2003). Sušenje sadja. Ljubljana: Samozaložba.

18. Vrhovnik, I. (2006). Kaki pri nas in v svetu. $S A D, 17(11)$, 3-4.

19. Zhou, C., Zhao, D., Sheng, Y., Tao, J., \& Yang, Y. (2011). Cartenoids in fruits of different persimmon cultivars. Molecules, 16, 624-636. 


\section{Vpliv priprave plodov na senzorično oceno suhih kakijev sorte 'Tipo' (Diospyros kaki L.)}

\section{IZVLEČEK}

Raziskava, izvedena na Fakulteti za kmetijstvo in biosistemske vede Univerze v Mariboru, temelji na preizkušanju potencialne všečnosti suhega kakija glede na različne oblike priprave plodov na sušenje. Ta se je razlikovala glede na umedenost plodov, debelino in obliko rezin ter pristnost kožice. Senzorično vrednotenje vzorcev je bilo izvedeno med študenti in zaposlenimi z uporabo hedonske lestvice, kjer so preskuševalci ocenili všečnost parametrov videza (oblika in barva) in okusa (razmerje med sladkorjem in kislino, tekstura, trpkost, prisotnost lupine - le pri enem obravnavanju in skupni vtis) vzorcev. Najvišjo oceno za videz je prejel vzorec, pripravljen iz neoplojenega in olupljenega kakija, narezanega na rezine debeline 3 mm. Z najvišjimi ocenami pri parametrih okusa pa je izstopal neoplojen olupljen krhelj. Ocene kažejo, da so oplojeni kakiji manj primerni za sušenje, saj so pri vseh spremljanih parametrih ocenjeni z najnižjimi ocenami, medtem ko prisotnost kožice ni moteča.

Ključne besede: kaki, sušenje, hedonska senzorična ocena 